\title{
Morphometric Analysis to Assess Sea Level History and Uplift Rate in the Pleistocene Marine Terraces of Chabahar
}

\author{
Sedigheh Farahi Ghasr-Aboonasr $^{1}{ }^{*}$, Julius Jara-Muñoz ${ }^{2}$ \\ 1- Iranian National Institute for Oceanography and Atmospheric Sciences, Tehran, Iran \\ 2- University of Potsdam, Potsdam, Germany
}

Received: July 2017

Accepted: March 2017

(C) 2017 Journal of the Persian Gulf. All rights reserved.

\begin{abstract}
Marine terraces have long been used as baseline geodetic markers of relative past sea levels, reflecting the interaction between vertical crustal movements and sea level oscillations. The terraces age and elevation of shoreline angles can be used to determine uplift rate. Disparate uplift rates in pervious investigation in the study area are related to manual measurements based on the surface morphology without considering erosion and other natural factors were deformed the marine terraces morphology. The uplift rate strongly depends on the temporal and spatial accuracy of shoreline angle measurement. In this research, Chabahar Marine Terrace has been assessed by using geologic information, morphometric analysis, and radiocarbon dating along with using of digital elevation model and TerraceM program to estimate accurate uplift rate and to determined mechanism of uplift. High-resolution topographic data and TerraceM program significantly simplify the remote identification of shoreline angles, to rapidly assess and map them at regional and local scales and providing accurate estimation of past sea levels. Uplift rate was estimated by 15 topographic swath profile along a sequence using digital elevation map. Calibrated radiocarbon ages of 3 samples fall between $46944 \pm 3055 \mathrm{yr}$ B.P. and $29304 \pm 557 \mathrm{yr}$ B.P., revealing that strata uplifted about $29 \mathrm{ka}$ years ago with a rate of between 2-5 mm/yr (average: $4 \mathrm{~mm} / \mathrm{yr}$ ). In general, uplift rates increase from west to east of the Chabahar Marine Terraces. However, some local increases or decreases in uplift rates were observed due to local tectonics. According to morphology of terraces, correlation of rock units, faults density and variations of thickness of litho-stratigraphic units, it is concluded that the coastal area of study can be divided into two separate zones I and II which can be separated by faults. The sequence of Chabahar Terrace coincides with the interstadial stage of Marine Isotope Stage 3 (MIS3). Chabahar wave-cut terrace has been built by uplift along with sea level rise at $29 \mathrm{ka}$ years ago. Altogether, considering the stability of sea level changes in the region, factors such as tectonics, erosion and sedimentary basin have determined the current shape of Chabahar Terraces.
\end{abstract}

Keywords: Chabahar, marine terrace, uplift rate, TerraceM

\section{Introduction}

Marine terraces are among the most important and

\footnotetext{
"Email: farahisedigheh@yahoo.com, farahisedigheh@inio.ac.ir
}

prominent geomorphic features along the Makran coasts of Iran and Pakistan. The presence of raised beaches and old marine terraces along the Makran coast suggest that tectonic uplift is a significant 
factor in formation of theses raised beaches. Surface Uplift in convergent margins such as Makran coasts can occur uninterruptedly by aseismic creep and/or in effect of large seismic events (Lajoie, 1986; Normand et al., 2019). Considering the duration of seismic cycle and timescale of emergence of marine terraces, the uplift mechanism has been determined. On the other hand, shoreline angle is the best indicator for sea level position at the time of platform formation. A principal reasons of the study of marine terrace is the dating of marine terrace sequences or geomorphic surfaces to assess the morphostratigraphic relationship to calculate the uplift rate and uplift mechanism in these coastal areas (JaraMunoz et al., 2015;Lajoie, 1986; Normand et al., 2019). Based on previous studies, Chabahar marine terraces have uplift rate more than $1 \mathrm{~mm} / \mathrm{yr}$ which are among the fastest area in the world for a subduction zone that usually uplifts at rates of less than $1 \mathrm{~mm} / \mathrm{yr}$ (Henry et al., 2014; Pedoja et al., 2011).

Therefore, the precise study of Pleistocene of Chabahar marine terrace where urban area is located deems very necessary. In perviouse investigations, the elevation of shoreline angle for estimation of uplift rate usually has been obtained through the surface morphology and manual measurements that is why different results have been achieved. Considering that subsequent processes such as erosion and other natural factors impact the marine terraces and deform this geodetic marker spatially and temporally. Thus, disparate uplift rates with underestimated uncertainties were estimated by these markers because there are strong correlations between estimated uplift rates and the precision of calculation of shoreline angle in time and space. Therefore, in this research, Chabahar Marine Terrace has been assessed by using geologic information, morphometric analysis, and radiocarbon dating along with using of digital elevation model and TerraceM program to estimate accurate uplift rate and determine mechanism of uplift. High-resolution topographic data and TerraceM program significantly simplify the remote identification of shoreline angles, to rapidly assess and map them at regional and local scales and providing accurate estimation of past sea levels positions.

\section{Regional tectonic and geologic setting}

Makran coast is part of Makran accretionary wedge, a part of Alpine- Himalayan Orogenic belt, has been formed by subduction of oceanic crust of Arabian Plate under the Lut and Afghan Blocks of Eurasian Plate at a rate of $4 \mathrm{~cm} /$ year in $\mathrm{N}-\mathrm{S}$ direction (DeMets et al., 1990; Dercourt et al., 1986; Jacob and Quittmeyer, 1979; Masson et al., 2007; Vigny et al., 2006) (Figure 1). The current geometry of Makran subduction zone due to deficiency of instrumental information is obscure but the general agreements based on seismic data, earthquakes focal mechanisms, seismic tomography images represents a northward shallow dipping slab $\left(\sim 2^{\circ}\right)$ (Bijwaard et al., 1998; Byrne et al., 1992; Hafkenscheid et al., 2006; Jacob and Quittmeyer, 1979). This structural zone extends nearly $1000 \mathrm{Km}$-long in southern part of Iran and Pakistan from the Strait of Hormuz in west to near the Karachi in east. It is separated on the west from the Zagros collision zone by the right lateral Minab fault system and to the east by Chaman, left lateral Ornach-Nal fault system and Own fracture zone from the Indian plate (Bird et al., 1975; Molnar and Stock, 2009; Stocklin, 1968) (Figure1).

This active continental margin of Makran is an accretionary wedge that displays evidences of progressive deformation since late Cretaceous (Berberian et al., 1982; Farhoudi and Karig, 1977; Hoffmann, 2016; Jacob and Quittmeyer, 1979; McCall, 2002). Differences in seismic behavior along the Makran from west to east characterize two 


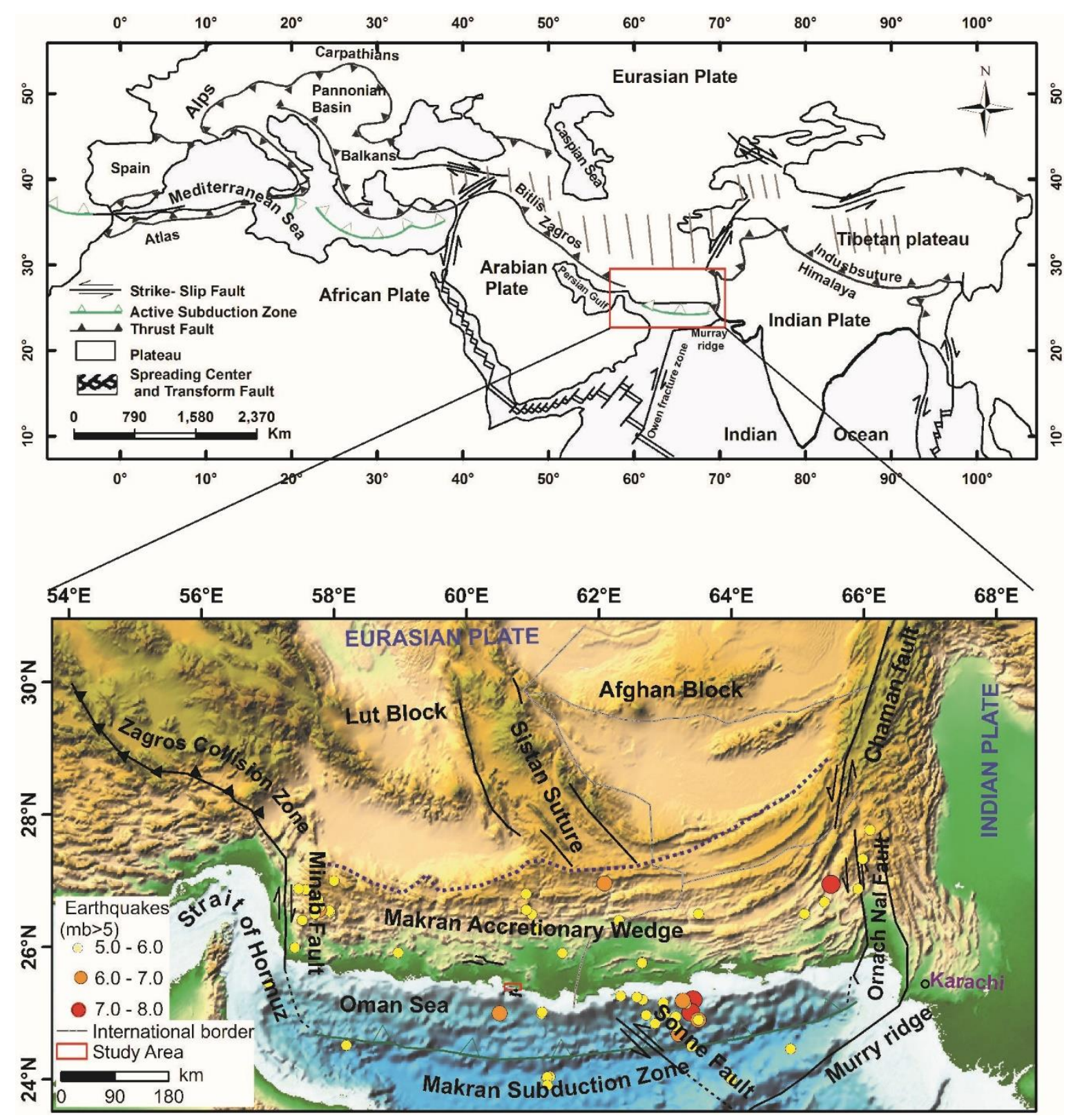

Fig 1: Tectonic setting of Makran subduction zone in Alpine Himalayan orogenic belt and the location of study area (red box) in Makran accretionary wedge superimposed on Global Relief Model (ETOPO1), with recorded earthquakes from 1900 to 2018 (mb>5) (for more details refer to the text).

separate part (western and eastern parts) which Sistan suture zone (Byrne et al., 1992; Zarifi, 2007) and the left lateral strike-slip Sonne Fault (Kukowski et al., 2001; Rajendran et al., 2013) has been proposed as the boundary of them.

The Makran subduction zone is characterized by scarce and low magnitude seismic events, most of them localized in the eastern part, such as large events in Pasni $\mathrm{M}_{\mathrm{w}} 8.1$ in1945 (Byrne et al., 1992; Hoffmann et al., 2013b; Penney et al., 2017; Zarifi and Raeesi, 2010). Despite the historical megathrust earthquakes in this part, now it has experienced very little seismic activity (small and medium-sized). Although, western Makran part is seismically calm, but suspicious evidence of historical earthquakes (events in 1008 and 1483, the exact information are 
poorly known), presence of mud volcanoes and raised beaches indicate that this region is tectonically active and most studies agree that it have the potential to produce tsunamigenic megathrust earthquakes in future (Ambraseys and Melville, 1982; Heidarzadeh et al., 2008; Hoffmann et al., 2013a; Pararas-Carayannis, 2006; Penney et al., 2017; Shah-hosseini et al., 2011; Waelbroeck et al., 2002). The earthquake catalogue from 1900 to 2017 shows that almost all earthquakes occur in this part is an average depth and often have normal faulting mechanism (NEIC, 2018) (Figure. 1).

Western Makran coast that is a part of tectonostratigraphic zone of coastal Makran, is characterized by erodible Miocene and Pliocene siltstone and mudstone with minor interbeds of sandstone which overlain by plio-pleistocene conglomerate, sandstone, shale and limestone, forming a wide flat coastal plain (Burg et al., 2013; McCall, 2002; Page et al., 1979).Coastal Makran weakly deformed and has experienced normal faulting (since the middle Pleistocene) not seen in other units of Makran (Burg et al., 2013; Dolati and Burg, 2013; Harms et al., 1984). On the Makran coast, multiple normal faults locally crosscutting the marine terraces and may result in differential uplift (Burg et al., 2013; Leggett and Platt, 1984; Marshak, 1988; Normand et al., 2019). The bedrock is locally interrupted and overlook by a series of prominent headlands stepped with marine terrace sequences. These headlands predominantly changes between sandstone and conglomerates with thin bedded silty marls (Dolati, 2010; Samadian et al., 1996). The headlands are generally flat-topped or gently tilted and are separated by wide omega shaped bay that show sequences of beach ridges of Holocene (Gharibreza, 2016; Shah-Hosseini et al., 2018). In this study, we focus on the marine terrace sequences of Chabahar, one of the best exposures of wave cut marine terraces in Makran Coast of Iran (Figure 1).

\section{Concepts and methods}

3.1. Marine terraces as a geomorphic indicator of paleo sea level

Marine terraces along tectonically active areas, as a geomorphic indicator reflect the interaction between vertical tectonic movements and sea level fluctuations (Jara-Muñoz et al., 2016). A wave cut marine terrace is formed during high stand periods and may be deserted as a marine sedimentary horizon during the next low-stand. If uplift rate is fast enough, this horizon can be preserved at higher elevations during the next high stand period as a marine terrace while a new marine terrace will be created at lower elevation (Bradley and Griggs, 1976; Rosenbloom and Anderson, 1994). Wave cut marine terrace consist of flat and smooth surfaces (paleo-platforms) with gently dip seaward. The paleo-platforms are usually bounded inland by scarps or paleo-cliffs and determined by shoreline angle (SA) or inner edge where paleoplatform intersect paleocliff. The SA has been considered as the marine terrace elevation at formation time and is the best indicator of past sea level positions (Jara-Munoz et al., 2015; Jara-Muñoz et al., 2016; Lajoie, 1986). With the formation of new terrace surface and the uplifting of old surface over time, a staircase morphology is created which can be seen along the Makran coast (Konarak, Chabahar, ...) that has been correlated with sea level high- stands at time of formation (Page et al., 1979; Snead, 1993). The SA has been used for estimating the pure vertical displacement and corresponding uplift rate of a specific terrace level (Eq.1) (Ahmed, 1969; Jara-Muñoz et al., 2016; Lajoie, 1986). Marine terrace surfaces are fugacious landforms which have been affected by erosional and depositional processes immediately after their exposure. For example, in this procedure the terrace platforms and cliffs obliterated by river incision, erosion, slope diffusion and the SA is often disappeared by eolian 
and colluvial deposits. In order to appear the primitive terrace morphology, the SA has been estimated by an efficient method and using accurate digital elevation models (DEMs) that is described in section 3.4.

\subsection{Field studying and Shoreline angle elevation}

Geologic field studying concentrated on specifying the type of terrace surface, place of paleo- cliffs, stratigraphy, thickness of associated sedimentary deposits and sampling for age. To perform morphometric analysis of the Pleistocene marine terraces in Chabahar, we used 10-meterresolution DEM map (Figure.2) (NCC, 2016) then the SA elevation was determined by a profile -based analysis. The accuracy of determining of terrace elevation is extremely important to get valid uplift rates. The main issue when mapping SA elevations is
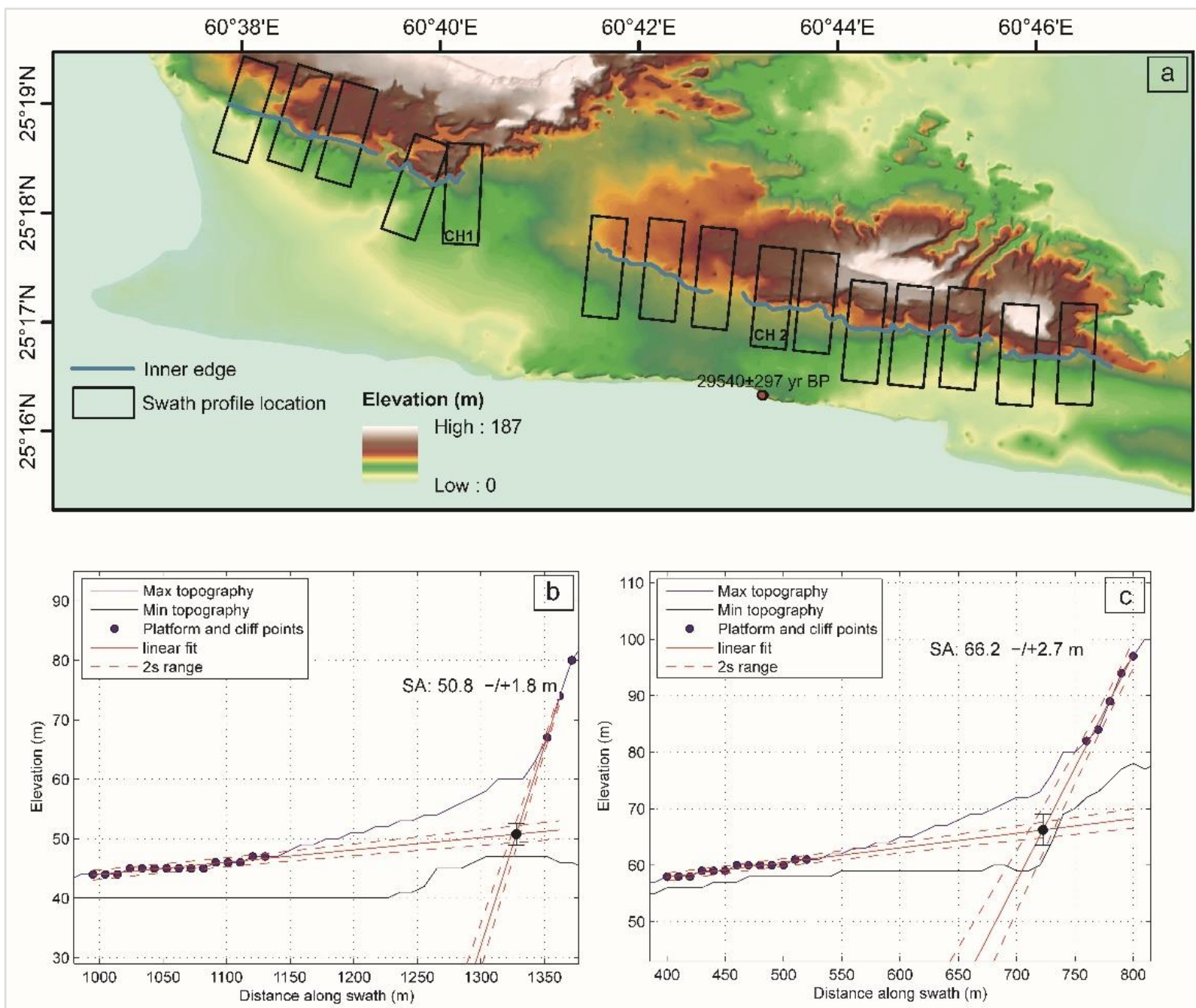

Fig 2: (a) 10-meter precision DEM map of Chabahar marine terraces showing the location of inner edge (thick blue lines) and swath profiles (red boxes) oriented perpendicular to the inner edge and analysis by TerraceM program. (b) Diagram of staircase analysis function of $\mathrm{CH}_{1}$ swath profile (its location was determined in (a) with 20 error. Paleo-platform and pleo-cliff are shown by points on diagram and the position of SA obtained by linearly extrapolation of paleo-platform and between defined points by user. (c) Diagram of staircase analysis function of $\mathrm{CH}_{2}$ swath profile (its location was determined in (a) with similar procedure to $\mathrm{CH}_{1}$. 
that the original terrace morphology is usually dismantled by river incision, or masked by cliff diffusion and eolian deposits or a combination of these processes (Hanks et al., 1984; Jara-Munoz et al., 2015; Jara- Muñoz et al., 2016).

In order to reconstruct the original terrace morphology, we used TerraceM, a MATLAB® tool to analyze staircase marine terraces and map their shoreline angles (Jara-Muñoz et al., 2016). TerraceM uses the maximum topographic distribution extracted from topographic swath profiles, in order to be restore the pre-incision topography and to avoid the effects of fluvial overprints and erosional processes (Figure 2).

The SA is located by extrapolating and intersecting linear regression representing the paleoplatform and paleo-cliff. The vertical errors are based the $95 \%$ confidence interval of the linear regressions (Figure 2). In Figure 2, $\mathrm{CH}_{1}$ and $\mathrm{CH}_{2}$ are two examples of swath profiles illustrating the methodology used at staircase Chabahar marine terraces.

\subsection{Radiocarbon dating}

Radiocarbon dating method was chosen to determine the age of Chabahar marine terrace due to abundance of mollusk shells (bivalves fragments and oyster shell) in marine terrace deposits. The calcitic mollusk shells were collected in situ from deposits for dating due to lower risk of displacement. Here, three samples collected from deposits of Chabahar marine terrace (CH-T3, CH-T1, CH-T4) (Table1), Samples consisted of oyster shell fragments in sandy allochem limestone matrix (allochem include large broken bivalves, gastropods, crinoids and foraminifera) at depth between 1 and $1.5 \mathrm{~m}$ below the surface. Samples after the preparation were sent to Poznan radiocarbon laboratory, where they were prepared, bleached and analyzed with the accelerator mass spectrometry (AMS) counting method. The radiocarbon dates were calibrated to calendar ages using CALIB.7.0.4 software (Stuiver and Reimer, 1993) with the calibration curve marine 13 , and a marine reservoir age correction of $\Delta \mathrm{R}=190 \pm 25$ years determined for the Arabian Sea (Southon et al., 2002) (Table1).

Table 1: Radiocarbon dating and calibrated ages with 1 and $2 \sigma$ errors for 3 samples from Chabahar marine terraces

\begin{tabular}{|c|c|c|c|c|c|c|c|c|c|}
\hline $\begin{array}{c}\text { Sample } \\
\text { Name }\end{array}$ & $\begin{array}{c}\text { Lab. } \\
\text { No. }\end{array}$ & Long (E) & Lat $(\mathbf{N})$ & $\begin{array}{c}\text { Elevation } \\
\text { (m) }\end{array}$ & $\begin{array}{c}\text { Sample } \\
\text { depth } \\
\text { (m) }\end{array}$ & $\begin{array}{c}\text { Age } \\
(y r \text { BP) }\end{array}$ & $\begin{array}{c}\text { Error } \\
(\mathrm{yr})\end{array}$ & $\begin{array}{c}\text { calibrat } \\
\text { e age } 1 \boldsymbol{\sigma} \\
(\mathrm{yr} \mathrm{BP})\end{array}$ & $\begin{array}{c}\text { calibrat } \\
\text { e age } \mathbf{2} \boldsymbol{\sigma} \\
(\mathrm{yr} \mathrm{BP})\end{array}$ \\
\hline CH-T-1 & $\begin{array}{l}\text { Poz- } \\
94031\end{array}$ & $60^{\circ} 41^{\prime} 19.24^{\prime \prime}$ & $25^{\circ} 16^{\prime} 34.52^{\prime \prime}$ & 19 & 1.5 & 31802 & 300 & $\begin{array}{c}31802 \pm \\
404\end{array}$ & $\begin{array}{c}31976 \pm \\
739\end{array}$ \\
\hline CH-T-3 & $\begin{array}{l}\text { Poz- } \\
94029\end{array}$ & $60^{\circ} 43^{\prime} 18.77^{\prime \prime}$ & $25^{\circ} 16^{\prime} 26.57^{\prime \prime}$ & 34 & 1 & 29273 & 220 & $\begin{array}{c}29273 \pm \\
269\end{array}$ & $\begin{array}{c}29304 \pm \\
557\end{array}$ \\
\hline CH-T-4 & $\begin{array}{l}\text { Poz- } \\
94030\end{array}$ & $60^{\circ} 40^{\prime} 37.32^{\prime \prime}$ & $25^{\circ} 16^{\prime} 32.73^{\prime \prime}$ & 7 & 1 & 48308 & 3000 & $\begin{array}{c}48308 \pm 1 \\
692\end{array}$ & $\begin{array}{c}46944 \pm \\
3055\end{array}$ \\
\hline
\end{tabular}

\subsection{Uplift rate using SA}

Marine terraces are commonly used as a geomorphic marker to estimate uplift rate based on eustatic correlations, and their elevation. Eustatic correlation is usually based on global sea level reconstructions; marine terrace ages can be correlated with sea level positions and associated to 
the nearest high-stand positions. We used the sealevel curve of Bintanja and Van de Wal (2008), which is the most recent high-resolution sea level curve for the Northern Hemisphere, compiled from 57 globally distributed sediment cores, over the last 3000 ka BP. A gridded DEM in Arc Asciigrid or Geotiff formats in UTM projection and polygons in ESRI shapefile format (Swath profiles) upload in TerraceM program as inputs to calculate SA (terrace elevation). Swath profiles are oriented orthogonal to the trace of the paleo-cliff or the terrace inner edge, surrounding the paleo-platform and paleo-cliff (Figure 2). In this purpose based on the DEM resolution and the terrace morphology, $600 \mathrm{~m}$ wide swath profiles with $1700 \mathrm{~m}$ length were utilized. Here we used 15 swath profiles (Figure 2) to calculate SA along the X-Y profile (Figure 5 Table 2).
The uplift rates have been estimated using the equation (Lajoie, 1986):

$U=\frac{\left(E_{T}-E_{S L}\right)}{t}$

Where $E_{T}$ is marine terrace elevation (SA elevation) and $E_{S L}$ the sea level position at the formation time of terrace. The difference between $E_{T}$ and $E_{S L}$ represents the relative sea level position. The uplift rate $(\mathrm{U})$ is obtained by dividing the relative sea level by the age of the terrace level (t). We also corrected the calibrated age with the nearest older sea level high-stand; eventually the SA elevation and the corrected age of terrace have been used to calculate the corrected uplift rate (Table 1).

Table 2: calibrated radiocarbone ages with corresponding elevations, paleo sea leveles and uplift rates.

\begin{tabular}{cccccccccc}
\hline $\begin{array}{c}\text { Sample } \\
\text { Name }\end{array}$ & $\begin{array}{c}\text { Sample } \\
\text { Elevation } \\
(\mathrm{m})\end{array}$ & Age & MIS & $\begin{array}{c}\text { Sea } \\
\text { level } \\
(\mathrm{ka})\end{array}$ & $\begin{array}{c}\text { Apparent } \\
\text { uplift rate } \\
(\mathrm{m} / \mathrm{ka})^{\mathrm{b}}\end{array}$ & $\begin{array}{c}\text { Marker } \\
\text { elevation } \\
(\mathrm{m})\end{array}$ & $\begin{array}{c}\text { Assigned } \\
\text { age }^{\mathbf{c}} \\
(\mathrm{ka})\end{array}$ & $\begin{array}{c}\text { Sea } \\
\text { level } \\
(\mathrm{m}){ }^{\mathrm{d}}\end{array}$ & $\begin{array}{c}\text { Corrected } \\
\text { uplift rate } \\
(\mathrm{m} / \mathrm{ka})\end{array}$ \\
\hline CH-T-1 & 19 & $31.9 \pm 0.7$ & MIS3 & -99 & 3.6 & $60 \pm 0.91$ & 32 & -98.4 & $4.9 \pm 0.02$ \\
CH-T-3 & 34 & $29.3 \pm 0.5$ & MIS3 & -105 & 4.7 & $66.2 \pm 2.7$ & 32 & -98.4 & $5.1 \pm 0.08$ \\
CH-T-4 & 7 & $46.9 \pm 3.05$ & MIS3 & -79 & 1.9 & $50.8 \pm 1.8$ & 46.1 & -78.9 & $2.8 \pm 0.03$ \\
\hline
\end{tabular}

\footnotetext{
${ }^{\text {a }}$ sea level based on Bintanja and Van de Wal (2008)

${ }^{\mathrm{b}}$ Apparent uplift obtained directly from sample age and elevation

${ }^{c}$ Assigned nearest last highstand age

${ }^{\mathrm{d}}$ sea-level at assigned highstand
}

\section{Results and Discussion}

\subsection{Stratigraphy and radiocarbon dating of Chabahar marine terrace deposites}

Chabahar marine terraces are the youngest deposits of Pliocene-Pleistocene marine deposits on Chabahar headland in eastern part of Iranian Makran coast (Dolati, 2010). We studied elevation changes and thickness of sedimentary layers at 7 locations in study area (Figure 3). In the studied locations, two general sedimentary unites, upper unit (UU) and lower unit (LU) were considered based on stratigraphy and depositional environment. The upper unit consists of thin to medium- bedded, reddish brown, well consolidate grainstone (sandy allochem limestone) (Figure 3) or coquina beds and allochem sandstones. The allochems composed of broken bivalves, crinoids, gastropods, foraminifera and carbonate intraclasts. There are also sub-angular to broken rounded extra basinal grains with a different grain size that show high energy basin. 
Sedimentary structures, such as hummocky crossstratification, asymmetric ripples, high-angle planar cross-bedding, the coarsening-upward with some lamination interbeds have been observed in this unit that suggests, shallow marine environment, backshore to upper shoreface sedimentation basin (Einsele, 2013; Harms et al., 1984). Below this unit, there is an unconformity characterized by wide range of grain size which include coarse grains (boulders, gravel) to medium and fine grain (sand, silt, clay) and large bivalves indicate storm generated bed. Two samples CH-T3, CH-T1 (Table 1) are collected respectively from the upper and lower part of this unit aged between $29304 \pm 557$ to $31976 \pm 739 \mathrm{yr}$.

The lower unit consists of thin bedded, greyish olive of fine to very fine-grained sandstone and light greyish olive to pale grey of mudrock with interbedded siltstones and very fine-grained sandstones. This unit is characterized with structures, such as lamination (abundantly), cross lamination, burrows, and channels filled with pebbles and bioclasts with different sizes that are associated wiyh middle shoreface to offshore environment (Einsele, 2013; Harms et al., 1984). The CH-T4 radiocarbon sample was picked from the lowest layer of this unit are aged about $46944 \pm 3055$ yr.

The variations in Thickness of UU and LU was investigated in 7 locations (S1, S2, .., S7) (Figure $3)$. The thickness of these two units decreases from $\mathrm{S} 1$ to $\mathrm{S} 3$, which suddenly increase again at S4. From there toward the $\mathrm{S} 7$, a decreasing trend can be seen. Due to the stability of eustatic sea level changes in the region, local tectonics is responsible for these changes.

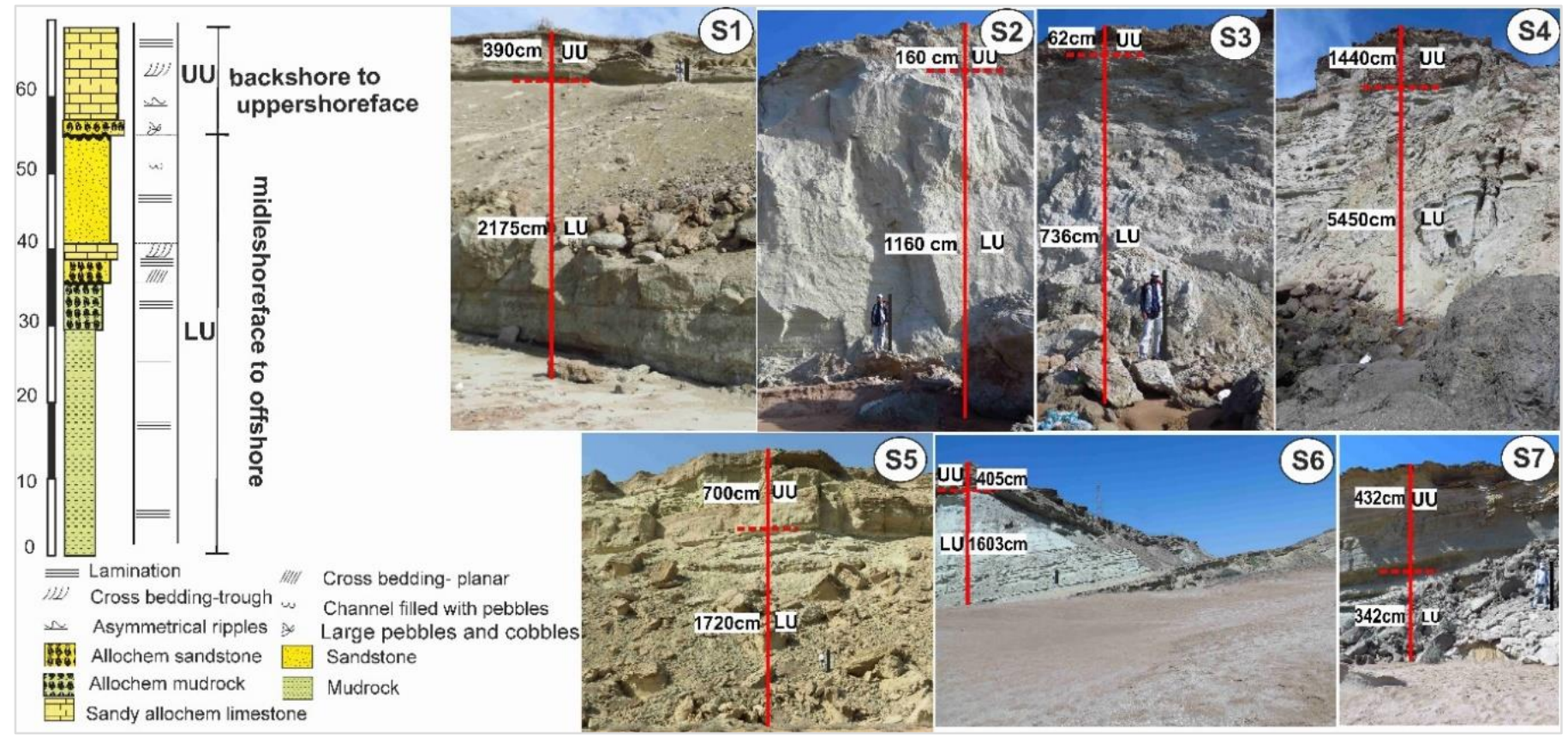

Fig 3: Schematic stratigraphic section and S1 to S7 locations marked on Figureure 2. Two general parts of the upper unit (UU) and the lower unit (LU) and their thickness are specified in each location.

4.2. Interpretation of the uplift rate and elevation changes along the Chabahar marine terrace

Based on the radiocarbon dating by using LR04 data for determination of MIS and intervals, it is determined that Chabahar marine terrace was deposited during the MIS3 (see Figure 4) a period between 57 and $29 \mathrm{ka}$ ago (Lisiecki and Raymo, 2005;Railsback et al., 2015) (Figure 4a). Sea level variation during MIS3 was approximately 80-105 m 
below its present-day elevation (Bintanja and Van de Wal, 2008) (Figure 4b). In order to estimate uplift rate using Eq. 1 at first, we calculated relative sea level location based on difference between terrace elevation and sea level location at the time of terrace formation. Therefore, sea level position at the formation time extracted from sea level curve of Bintanja \& Van de Wal (2008).

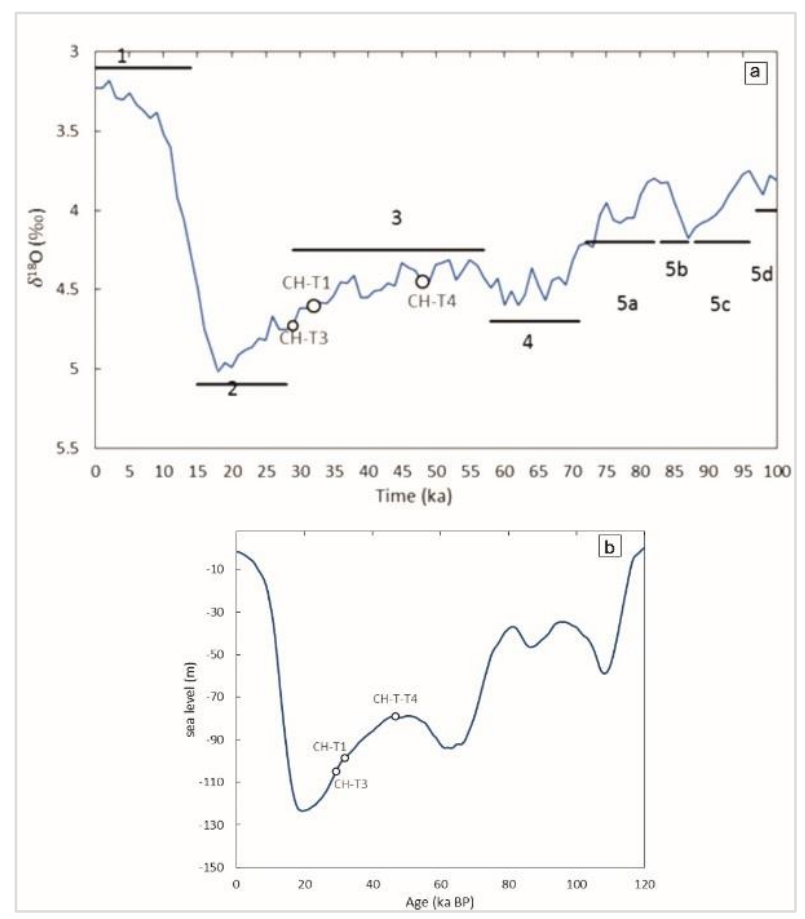

Fig 4: (a) Marine isotope stages and sub-stages for last $100 \mathrm{ka}$ based on LRo4 data set obtained from $\sigma^{18} \mathrm{O}$ record of benthic foraminifers (Lisiecki and Raymo, 2005) ${ }^{14} \mathrm{C}$ ages plotted at corresponding paleo sea level positions. Horizontal lines represent the length of Isotope stages or sub-stages.

(b) Global sea-level curve of Bintanja and Van de Wal (2008) with ${ }^{14} \mathrm{C}$ ages ( $2 \sigma$ errors) projected at their sea level positions at the formation time.

The uplift rate by using SA values from 15 swath profile, based on the apparent uplift rate and corrected uplift rate values is determined between 2-5 mm/yr with an average $4 \mathrm{~mm} / \mathrm{yr}$ (Table 2). The uplift rate from $X$ that is the location of first profile increasing to the east direction to Y. A significant increase at uplift rate between fifth and sixth swath profile is visible and it also slightly increase in tenth swath that is the result of local tectonics and quaternary normal faults such as F1 and F2, which are the NE-trending and $\operatorname{dip}>45^{\circ} \mathrm{NW}$ faults with oblique-slip displacements crosscutting marine terrace deposits (Figure 6). The average value of uplift rate in previous studies estimates $1-2 \mathrm{~mm} / \mathrm{yr}$ (Page et al., 1979), 2.7 mm/yr (Vita-Finzi, 1980), 1.6 $\mathrm{mm} / \mathrm{yr}$ (Vita-Finzi, 1987), and $0.2 \mathrm{~mm} / \mathrm{yr}$ (Reyss et al., 1999). Considering the high dependence of estimated uplift rates on the accuracy of shoreline angle elevation measurements and the effects of erosion and other natural factors on concealing this adequate marker, it is obvious that there are differences between measurement by previous researchers without the use of modern tools and high-resolution topographic data in this study.

\subsection{Mechanism of uplift}

The elevation from S1 to S3 locations (from east to west) (Figure 3) show a decreasing trend. It increases in S4 with a decreasing trend toward S7. Considering to the morphology, thickness of rock units and uplift rate changes of Chabahar marine terrace, the study area can be divided into two general fault zone I and II (Figure 6). These twozone bounding by faults, NE trending and dip $>45^{\circ}$, one of these faults is well exposed between S5 and S6 in Figure 2. Investigating the occurred earthquake in the region from 1900 to 2018 indicates that no earthquake has been occurred in the study area and a few earthquakes with $m b<5$ occurred in the adjacent area of the Gulf of Oman (NEIC, 2018) (Figure 6).

Therefore, it can be concluded that these faults are not the seismogenic thrust faults parallel of the coastline and these faults are normal faults reported by Leggett and plat (1984), Marshak (1988) and Normand et al (2019) in the coast of Makran. On the Makran coast, multiple normal faults crosscutting 


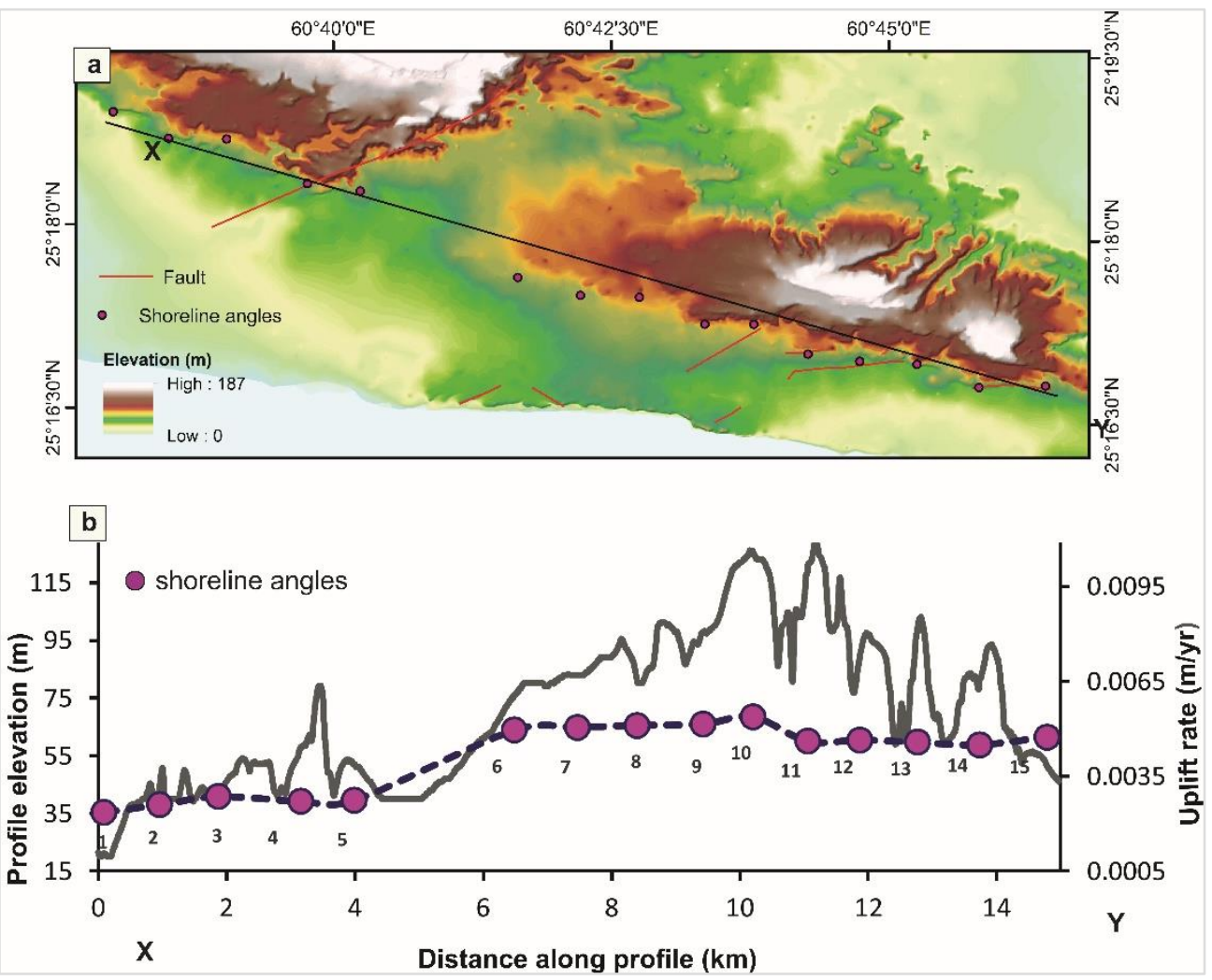

Fig 5: Chabahar Marine Terraces.

(a) Distribution of shoreline angles and main quaternary structures in the Chabahar marine terraces on 10-m DEM. Black line (XY) indicates location of profile line assesses in b.

(b) estimated uplift rates based on swath profiles and shoreline angles elevation along the XY.

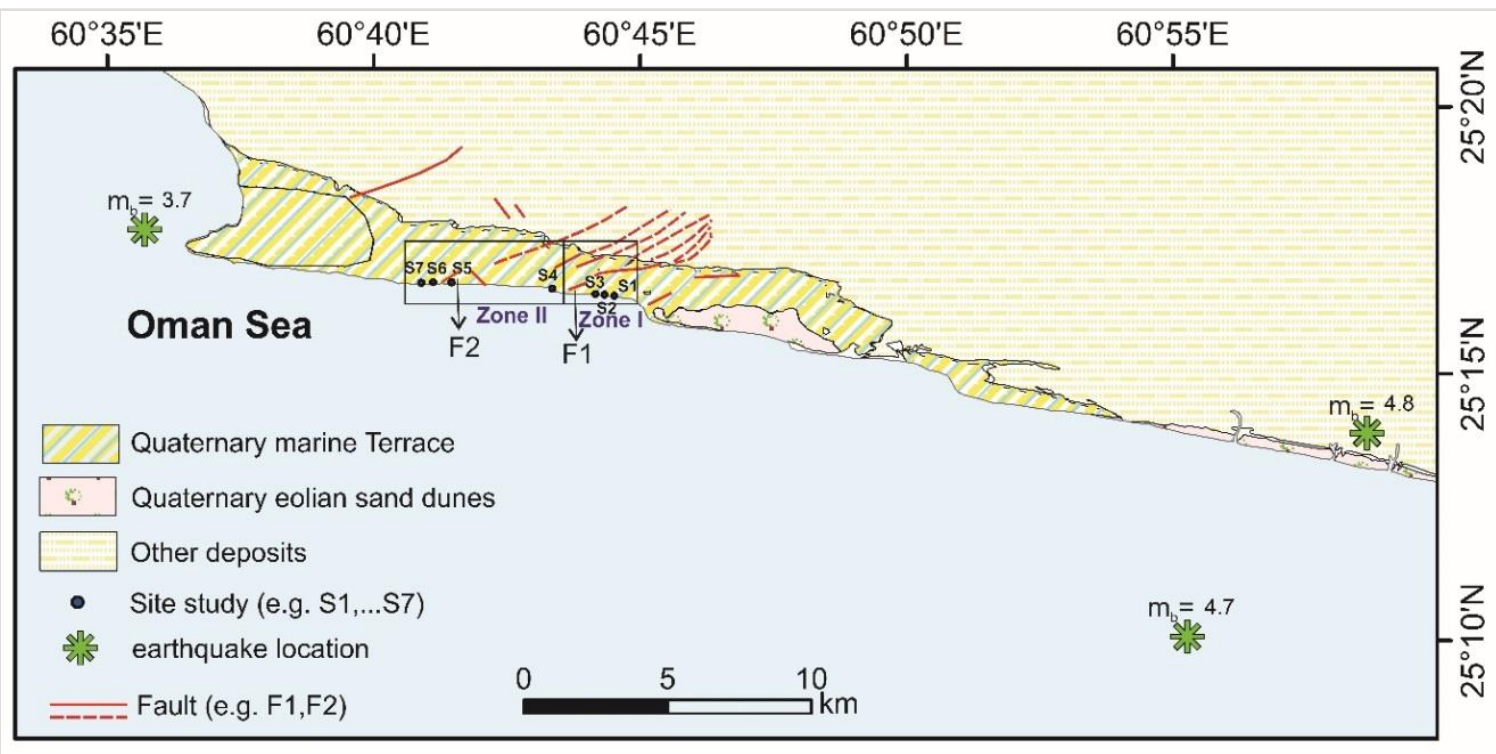

Fig 6: Simplified structural map of Quaternary Chabahar marine terraces with earthquakes distribution occurred in the area from 1900 to 2018, and faults affected on their morphology.

Area is located between S1 ... S7 locations is divided into two zones (zone I and II) in terms of the faults density, morphological changes and correlation of rock units (modified after 1/100,000 map of Chabahar geological map of geological survey and mineral explorations of Iran). 
terrace deposits in the study area and locally contribute to differential uplift. Hoseini -bazri and Talbot (2003) have expressed that the oblique-slip thrusts near the coast temporarily invert to these normal faults. This idea probably is not correct considering the lack of the large historical or instrumental earthquakes (except a dubious earthquake in 1483) and occurrence of earthquakes with average depth and often normal fault mechanism in the western part of the subducted plate. Geodetic data are rare, but modern GPS measurements document a nearly N-S shortening in coastal region that corroborated by Arabian plate subduct northward beneath the Eurasian plate (Figure 1). However, the normal faults formed near the surface indicate $\mathrm{N}-\mathrm{S}$ extension while convergence effects are limited to greater depth (Byrne et al., 1992; Jacob and Quittmeyer, 1979). The mechanism of formation of normal faults as the result of convergent and shortening remains a discussible question because of scarce data. A hypothesis for this discrepancy in kinematics during the interseismic period (i.e., now) is that the region has experienced $\mathrm{N}-\mathrm{S}$ convergence, whereas impressed by short episodes of $\mathrm{N}-\mathrm{S}$ extension in response to large ruptures on the subduction interface similar to what was observed in 2011 Tohoku megathrust earthquake (Hardebeck, 2012; Kato et al., 2011).

\section{Conclusions}

Pleistocene staircase marine terraces of Chabahar, where chabahar city is located, is a nearly flat marine terrace. Two general lithostratigraphy units (upper unit and lower unit) have been considered in this study. According to their lithofacies and dominant sedimentary structures, depositional environments are backshore to upper shoreface and middle shoreface to offshore. The upper unit was deposited from $29.3 \pm 0.5 \mathrm{ka}$ to $31.9 \pm 0.7 \mathrm{ka}$ years ago and the base layer (oldest layer) of this unit aged to $46.9 \pm 3.05 \mathrm{ka}$. Pleistocene marine terrace of Chabahar is related to MIS3 when the sea level position was 40 to $104 \mathrm{~m}$ below the present-day level. Shoreline angle elevations changes between $33 \mathrm{~m}$ and $73 \mathrm{~m}$ along the study area illustrate decreasing westward though local increase is visible. The net rise in global sea level was at least $40 \mathrm{~m}$ since the formation of upper unit at around $29 \mathrm{ka}$, it cannot responsible for elevation between 33 and 73 above at the present day. The results of estimation of uplift rates by using 15 swath profile along this coastal segment indicate the differential uplift rate $(2-5 \mathrm{~mm} / \mathrm{yr})$ that can be assigned to action of normal faults and local tectonic effects. Minimum value of uplift rate $(2.3 \mathrm{~mm} / \mathrm{yr}$ is related to westward end of zone I and the maximum value $(5.4 \mathrm{~mm} / \mathrm{yr})$ as to eastward end of zone II. Two fault zones I and II bounded with normal faults have been determined in the study area, according to the morphology, thickness of rock units and uplift rate changes. These normal faults are near the surface in contrast to deep thrust faults and resulted by large ruptures in short episodes of extension.

\section{Acknowledgements}

This work was supported by the Iranian National Institute for Oceanography and Atmospheric Science. The authors are indebted to R. Jokar and M. Afarin for their help $f$ or the field works.

\section{References}

Ambraseys, N. N., Melville, C. P., 1982. A history of Persian earthquakes. Cambridge university press. Bijwaard, H., Spakman, W., and Engdahl, E. R., 1998, Closing the gap between regional and global travel time tomography: Journal of Geophysical Research. Solid Earth. 103(B12): 30055-30078. https://doi.org/10.1029/98JB02467 
Bintanja, R., Van de Wal, R., 2008. North American ice-sheet dynamics and the onset of 100,000-year glacial cycles. Nature. 454(7206): 869-872.

https://doi.org/10.1038/nature07158

Bird, P., Toksöz, M. N., Sleep, N. H.,1975. Thermal and mechanical models of continent- continent convergence zones. Journal of Geophysical Research. 80(32): 4405-4416.

https://doi.org/10.1029/JB080i032p04405

Burg, J.-P., Dolati, A., Bernoulli, D., Smit, J., 2013. Structural style of the Makran Tertiary accretionary complex in SE-Iran, Lithosphere dynamics and sedimentary basins. The Arabian Plate and analogues, Springer, 239-259.

https://doi.org/10.1007/978-3-642-30609-9 12

Byrne, D. E., Sykes, L. R., Davis, D. M., 1992. Great thrust earthquakes and aseismic slip along the plate boundary of the Makran subduction zone. Journal of Geophysical Research: Solid Earth. 97(B1): 449-478.

\section{https://doi.org/10.1029/91JB02165}

DeMets, C., Gordon, R. G., Argus, D., Stein, S., 1990. Current plate motions. Geophysical journal international. 101(2): 425-478.

https://doi.org/10.1111/j.1365-

246X.1990.tb06579.x

Dercourt, J., Zonenshain, L., Ricou, L.-E., Kazmin, V., Le Pichon, X., Knipper, A., Grandjacquet, C., Sbortshikov, I., Geyssant, J., and Lepvrier, C., 1986. Geological evolution of the Tethys belt from the Atlantic to the Pamirs since the Lias. Tectonophysics. 123: 241-315.

\section{https://doi.org/10.1016/0040-1951(86)90199-X}

Dolati, A., 2010. Stratigraphy, structural geology and low-temperature thermochronology across the Makran accretionary wedge in Iran.

Dolati, A., and Burg, J.-P., 2013. Preliminary fault analysis and paleostress evolution in the Makran
Fold-and-Thrust Belt in Iran, Lithosphere Dynamics and Sedimentary Basins. The Arabian Plate and Analogues, Springer, 261-277. https://doi.org/10.1007/978-3-642-30609-9 13

Einsele, G., 2013. Sedimentary basins: evolution, facies, and sediment budget, Springer Science \& Business Media. ETOPO1, Global Relief Model doi:10.7289/V5C8276M.

Gharibreza, M., 2016. Evolutionary trend of paleoshorelines in the Coastal Makran zone (Southeast Iran) since the midHolocene.Quaternary International, 392: 203-212. https://doi.org/10.1016/j.quaint.2015.06.030

Grando, G., McClay, K., 2007. Morphotectonics domains and structural styles in the Makran accretionary prism, offshore Iran. Sedimentary Geology. 196(1): 157-79.

https://doi.org/10.1016/j.sedgeo.2006.05.030

Hafkenscheid, E., Wortel, M., Spakman, W., 2006. Subduction history of the Tethyan region derived from seismic tomography and tectonic reconstructions. Journal of Geophysical Research: Solid Earth. 111(B8). https://doi.org/10.1029/2005JB003791

Hardebeck, J. L., 2012. Coseismic and postseismic stress rotations due to great subduction zone earthquakes. Geophysical Research Letters. 39(21).

\section{https://doi.org/10.1029/2012GL053438}

Harms ,J., Cappel, H., Francis, D., 1984. The Makran coast of Pakistan: its stratigraphy and hydrocarbon potential. Marine geology and oceanography of Arabian Sea and coastal Pakistan. $3(27)$.

Heidarzadeh, M., Pirooz, M. D., Zaker, N. H., Yalciner, A .C., Mokhtari, M., Esmaeily, A., 2008. Historical tsunami in the Makran Subduction Zone off the southern coasts of Iran and Pakistan and 
results of numerical modeling. Ocean Engineering. 35(8-9): 774-786.

https://doi.org/10.1016/j.oceaneng.2008.01.017

Henry, H., Regard, V., Pedoja, K., Husson, L., Martinod, J., Witt, C., Heuret, A., 2014. Upper Pleistocene uplifted shorelines as tracers of (local rather than global) subduction dynamics. Journal of Geodynamics. 78: 8-20.

\section{https://doi.org/10.1016/j.jog.2014.04.001}

Hoffmann, G., Reicherter, K., Wiatr, T., Grützner, C., Rausch, T., 2013a. Block and boulder accumulations along the coastline between Fins and Sur (Sultanate of Oman): tsunamigenic remains?. Natural hazards. 65(1): 851-873.

https://doi.org/10.1007/s11069-012-0399-7

Hoffmann, G., Rupprechter, M., Balushi, N. A., Grützner, C., Reicherter ,K., 2013b. The impact of the 1945 Makran tsunami along the coastlines of the Arabian Sea (Northern Indian Ocean)-a review: Zeitschrift für Geomorphologie, Supplementary Issues. 57(4): 257-277. https://doi.org/10.1127/0372-8854/2013/S-00134

Jacob, K. H., Quittmeyer, R. L., 1979. The Makran region of Pakistan and Iran: Trench-arc system with active plate subduction. Geodynamics of Pakistan. 305: 317.

Jara-Munoz, J., Melnick, D., Brill, D., Strecker, M. R. J. Q. S. R., 2015. Segmentation of the 2010 Maule Chile earthquake rupture from a joint analysis of uplifted marine terraces and seismiccycle deformation patterns. 113: 171-192. https://doi.org/10.1016/j.quascirev.2015.01.005

Kato, A., Sakai, S. i., Obara, K., 2011. A normalfaulting seismic sequence triggered by the 2011 off the Pacific coast of Tohoku Earthquake: Wholesale stress regime changes in the upper plate. Earth, planets and space. 63(7): 43. https://doi.org/10.5047/eps.2011.06.014
Kukowski, N., Schillhorn, T., Huhn, K., von Rad, U., Husen, S., Flueh, E. R., 2001. Morphotectonics and mechanics of the central Makran accretionary wedge off Pakistan: Marine Geology. 173(1): 119.

https://doi.org/10.1016/S0025-3227(00)00167-5

Lajoie, K. R., 1986. Coastal tectonics. Active tectonics, 95-124.

Leggett, J., Platt, J., 1984. Structural features of the Makran fore-arc on Landsat imagery: Marine Geology and Oceanography of Arabian Sea and Coastal Pakistan. Van Nostrand Reinhold, New York, 33: 44.

Lisiecki, L. E., Raymo, M. E., 2005. A PliocenePleistocene stack of 57 globally distributed benthic $\delta 180$ records. Paleoceanography, 20(1). https://doi.org/10.1029/2004PA001071

Marshak, S., 1988. Kinematics of orocline and arc formation in thin- skinned orogens. Tectonics. 7(1): 73-86.

https://doi.org/10.1029/TC007i001p00073

Masson, F., Anvari, M., Djamour, Y., Walpersdorf, A., Tavakoli, F., Daignières, M., Nankali, H., Van Gorp, S., 2007. Large-scale velocity field and strain tensor in Iran inferred from GPS measurements: new insight for the present-day deformation pattern within NE Iran. Geophysical Journal International. 170(1): 436-440. https://doi.org/10.1111/j.1365-246X.2007.03477.x

McCall, G., 2002. A summary of the geology of the Iranian Makran: Geological Society, London, Special Publications. 195(1): 147-204. https://doi.org/10.1144/GSL.SP.2002.195.01.10

Molnar, P., Stock, J. M., 2009. Slowing of India's convergence with Eurasia since $20 \mathrm{Ma}$ and its implications for Tibetan mantle dynamics. Tectonics. 28(3).

https://doi.org/10.1029/2008TC002271 
NEIC, 2018. National Earthquake Information Center. Normand, R., Simpson, G., Herman, F., Biswas, R. H., Bahroudi, A., Schneider, B., 2019. Dating and morpho-stratigraphy of uplifted marine terraces in the Makran subduction zone (Iran). Earth Surface Dynamics. 7(1): 321-344. https://doi.org/10.5194/esurf-7-321-2019

Page, W. D., Alt, J. N., Cluff, L. S., Plafker, G., 1979. Evidence for the recurrence of large magnitude earthquakes along the Makran coast of Iran and Pakistan. Developments in Geotectonics. 13: 533-547.

https://doi.org/10.1016/B978-0-444-41783$1.50081-7$

Pararas-Carayannis, G., 2006. The potential of tsunami generation along the Makran Subduction Zone in the northern Arabian Sea: Case study: The earthquake and tsunami of November 28, 1945. Science of Tsunami Hazards. 24(5): 358-384.

Pedoja, K., Husson ,L., Regard, V., Cobbold, P. R., Ostanciaux, E., Johnson, M. E., Kershaw, S., Saillard, M., Martinod, J., Furgerot, L., 2011. Relative sea-level fall since the last interglacial stage: are coasts uplifting worldwide? EarthScience Reviews. 108(1-2): 1-15. https://doi.org/10.1016/j.earscirev.2011.05.002

Penney, C., Tavakoli, F., Saadat, A., Nankali, H. R., Sedighi, M., Khorrami, F., Sobouti, F., Rafi, Z., Copley, A., Jackson, J., 2017. Megathrust and accretionary wedge properties and behaviour in the Makran subduction zone. Geophysical Journal International. 209(3): 1800-1830. https://doi.org/10.1093/gji/ggx126

Railsback, L. B., Gibbard, P. L., Head, M. J., Voarintsoa, N. R. G., Toucanne, S., 2015. An optimized scheme of lettered marine isotope substages for the last 1.0 million years, and the climatostratigraphic nature of isotope stages and substages. Quaternary Science Reviews.111: 94106.

https://doi.org/10.1016/j.quascirev.2015.01.012

Rajendran, C., Rajendran, K., Shah-Hosseini, M., Beni, A. N., Nautiyal, C., Andrews, R., 2013. The hazard potential of the western segment of the Makran subduction zone, northern Arabian Sea. Natural hazards. 65(1): 219-239.

https://doi.org/10.1007/s11069-012-0355-6

Samadian, M. R., Ghomashi, A., Mohebbi, A. R. J., M.B., Abdoli, M., Ahmadzadeh Heravi, M., 1996. Geological map of Iran 1 / 100000, Chabahar sheet, Geological Survey of Iran.

Shah-Hosseini, M., Ghanavati, E., Morhange, C., Beni, A. N., Lahijani, H. A., Hamzeh, M. A., 2018. The evolution of Chabahar beach ridge system in SE Iran in response to Holocene relative sea level changes. Geomorphology. 318: 139-147. https://doi.org/10.1016/j.geomorph.2018.06.009

Shah-hosseini, M., Morhange, C., Beni, A. N., Marriner, N., Lahijani, H., Hamzeh, M., Sabatier, F., 2011. Coastal boulders as evidence for highenergy waves on the Iranian coast of Makran. Marine Geology. 290(1-4): 17-28. https://doi.org/10.1016/j.margeo.2011.10.003

Stocklin, J., 1968. Structural history and tectonics of Iran: a review. AAPG Bulletin. 52(7): 1229-1258. https://doi.org/10.1306/5D25C4A5-16C1-11D7$\underline{8645000102 \mathrm{C} 1865 \mathrm{D}}$

Vernant, P., Nilforoushan, F., Hatzfeld, D., Abbassi, M., Vigny, C., Masson, F., Nankali, H., Martinod, J., Ashtiani, A., Bayer, R., 2004. Present-day crustal deformation and plate kinematics in the Middle East constrained by GPS measurements in Iran and northern Oman. Geophysical Journal International. 157(1): 381-398. https://doi.org/10.1111/j.1365-246X.2004.02222.X

Vigny, C., Huchon, P., Ruegg, J. C., Khanbari, K., Asfaw, L. M., 2006. Confirmation of Arabia plate 
slow motion by new GPS data in Yemen. Journal of Geophysical Research: Solid Earth. 111(B2). https://doi.org/10.1029/2004JB003229

Waelbroeck, C., Labeyrie, L., Michel, E., Duplessy, J. C., McManus, J., Lambeck, K., Balbon, E., Labracherie, M., 2002. Sea-level and deep water temperature changes derived from benthic foraminifera isotopic records. Quaternary Science
Reviews. 21(1-3): 295-305.

https://doi.org/10.1016/S0277-3791(01)00101-9

Zarifi, Z., 2007. Unusual subduction zones: case studies in Colombia and Iran.

Zarifi, Z., Raeesi, M., 2010. Heterogeneous coupling along Makran subduction zone, in Proceedings AGU Fall Meeting Abstracts 2010. 
